\title{
Is Periodontitis the Missing Link? A Metaethnographic Review of Glycemic Control Measures by Nigerian Diabetologists
}

\section{Solomon O. Nwhator ${ }^{1,2 *}$ and Michael A Adedigba ${ }^{2}$}

${ }^{1}$ Independent researcher, Manchester, UK

${ }^{2}$ Department of Preventive \& Community Dentistry, Faculty of Dentistry, Obafemi Awolowo University, Ile-Ife, Nigeria

\begin{abstract}
Diabetologists have always been aware of the adverse infect of infection on glycemic control. Periodontitis is a state of chronic subclinical inflammation exerting a similar adverse influence on glycemic control.

The mortality of diabetes mellitus in Nigeria remains high despite attempts at "tight glycemic control" using diet, life style modification, oral hypoglycemic and insulin. Reported attainment of glycemic control is at times as low as $15 \%$. The result of the failure in meeting glycemic control targets has taken in toll on the life of Nigerians and stretched our meager resources to the limits due to frequent admissions as a result hyperglycemic emergencies. These emergencies leave in their trail, reduced sexual function, microangiopathy and attendant end stage renal disease, blindness, limb amputations and death,

Could lack of consideration for periodontitis be the missing link in the glycemic control protocols of Nigerian diabetologists?

Using the search phrase Nigeria AND (diabetes OR diabetic OR diabetics), we conducted a search of existing literature in Cochrane Library, MEDLINE (PubMed), Mesh (MEDICAL SUBJECT HEADINGS (MeSH) databases. An initial number of 709 results were trimmed to 31 after application of inclusion criteria. We conducted a combination of metaethnography and narrative synthesis on the 31 studies and arrived at the hypotheses that the average Nigerian diabetologists appears UNAWARE of the link between glycemic control and periodontitis. Urgent training is recommended for Nigerian diabetologists through continuing education courses and collaboration with periodontologists.
\end{abstract}

Keywords: Diabetes mellitus; Nigeria; Periodontitis; Glycemic control

Key messages: The mortality of diabetes mellitus remains high in Nigeria. Despite advances in the multidisciplinary management of diabetes mellitus, Nigerian doctors appear largely unaware of this silent cause of poor glycemic control. Could this hold the key to significant success of poor glycemic control among Nigerian diabetics?

\section{Background}

Periodontitis is a state of chronic inflammation resulting in increased levels of proinflammatory mediators which increases insulin resistance resulting in poor glycemic control [1]. Periodontitis increases the risk of developing diabetes-associated complications by promoting the occurrence, progression and severity of diabetes [2]. Based on these findings, a team of German researchers have recommended that periodontal treatment should be part of the diabetes management protocol [2].

Unfortunately, Nigerian diabetologists appear to be completely unaware of this missing link in difficult glycemic control with dire consequences. Diabetic foot gangrene accounted for $55 \%$ of amputations at the Lagos University Teaching Hospital [3]. Poor glycemic control and consequent diabetic hyperglycemic emergencies accounted for the highest number diabetes-related admissions at the University of Ilorin Teaching Hospital [4] and diabetes mellitus accounted for $18 \%$ of endstage renal disease among Nigerians $[5,6]$.

These sober statistics informed our decision to undertake this qualitative review as a preliminary step towards highlighting this costly omission by Nigerian diabetologists.

\section{Review Question}

The prevalence of diabetic hyperglycemic emergencies and attendant admissions and mortality [4] got us thinking of a missing link already explored in literature but virtually unknown among Nigerian diabetologists. We were concerned about the level of awareness of the link between chronic periodontitis and poor glycemic control among Nigerian diabetologists. We decided on this review to answer the following questions;

1. Is periodontal examination part of the current diabetes management protocol in Nigeria?

2. Do Nigerian diabetologists rule out chronic periodontitis in the management of poor glycemic control?

Being a qualitative review precluded the use of metaanalysis which is restricted to statistical of numerical outcomes of controlled clinical trials. We therefore settled for metasynthesis using the approach of a metaethnography of all available studies that met our inclusion criteria. Because of the ambiguities and lack of clear consensus on many aspects of a metaethnography, however, we decided to combine this review approach with a narrative synthesis as detailed in Table 1.

${ }^{*}$ Corresponding author: Solomon O. Nwhator, Independent researcher, Formerly at Department of Preventive \& Community Dentistry, Faculty of Dentistry, Obafem Awolowo University, Ile-Ife, Nigeria, E-mail: periodontologist2010@gmail.com, nwhator32@yahoo.com

Received November 28, 2011; Accepted February 13, 2012; Published February 15,2012

Citation: Nwhator SO, Adedigba MA (2012) Is Periodontitis the Missing Link? A Metaethnographic Review of Glycemic Control Measures by Nigerian Diabetologists. Dentistry 2:121. doi:10.4172/2161-1122.1000121

Copyright: (c) 2012 Nwhator SO, et al. This is an open-access article distributed under the terms of the Creative Commons Attribution License, which permits unrestricted use, distribution, and reproduction in any medium, provided the original author and source are credited. 


\section{Deciding What is Relevant to the Initial Interest Defining the focus of the synthesis}

A search on diabetes AND Nigeria yields thousands of unmanageable studies and distracts from our focus-- consideration of an important factor in glycemic control-- periodontitis. We realized that conducting a search on the attitudes of Nigerian diabetologists would also yield too few studies. To strike a balance therefore, we decided to focus on studies on the actions of diabetologists i.e., what they considered important while managing cases of difficult glycemic control or factors they considered important while instituting the socalled "tight glycemic control." This way, we attempted to read the "clinical mindset" of Nigerian diabetologists by investigating what clinical parameters they considered important while attempting to maintain "tight glycemic control." This decision yielded the dividends of more specific and better manageability of studies which helped us to quickly answer our review question.

\section{Locating relevant studies}

Locating relevant studies as an important part of deciding what is relevant to the initial interest. We searched Cochrane Library,
MEDLINE (PubMed), Mesh (MEDICAL SUBJECT HEADINGS $(\mathrm{MeSH})$ using the search phrase Nigeria AND (diabetes OR diabetic OR diabetics) (Table 2a).

\section{Inclusion decisions/ criteria}

we applied the limits set to "human," and "English" to the original 709 Pubmed hits to the search phrase Nigeria AND (diabetes OR diabetic OR diabetics). This streamlined the studies to 549. Adding the 32 hits from AJOL (African Journal Online) and Cochrane databases resulted in a total 590 studies. Further filtering of studies was performed using the term "glycemic control" and "control" resulting in 76 qualifying studies. To be included, a study had to be either an interventional study on glycemic control or one recommending interventions for tight glycemic control.

On these premises, 2 studies were excluded because they were written by dentists which were not diabetologists and 4 other studies were excluded because they were reviews not limited to Nigeria. The 2 case reports in our results were excluded due to the low evidence associated with such studies while 37 separate studies were excluded because were observational studies.

\begin{tabular}{|c|c|c|c|}
\hline Aim & \multicolumn{3}{|c|}{ To determine consideration of periodontitis among Nigerian diabetologists. } \\
\hline Search Strategy & \multicolumn{3}{|c|}{ Search phrase used: Nigeria AND (diabetes OR diabetic OR diabetics) yielding 750 studies } \\
\hline Quality assessment: & \multicolumn{3}{|c|}{7 Criteria used (Adapted to fit our research question) } \\
\hline Synthesis Approach: & \multicolumn{3}{|c|}{ Metaethnography combined with a bit of Narrative Synthesis } \\
\hline Key findings: & \multicolumn{3}{|c|}{$\begin{array}{l}\text { Diabetes mortality and morbidity still high in Nigeria, Glycemic control poor in most patients. Nigerian diabetologists appear to be } \\
\text { unaware of link between poor glycemic control and periodontitis. }\end{array}$} \\
\hline $\begin{array}{l}\text { Hypotheses resulting from } \\
\text { synthesis }\end{array}$ & \multicolumn{3}{|c|}{$\begin{array}{l}\text { Most Nigerian studies on diabetes have centered on microangiopathy, mortality and determinants of glycemic control. } \\
\text { None of the studies by Nigerian diabetologists have mentioned, considered or advocated periodontal evaluation as part of glycemic } \\
\text { control protocol for Nigerian diabetics. } \\
\text { Nigerian diabetologists appear unaware of the link between periodontitis and poor glycemic control. } \\
\text { Current unacceptable mortality and morbidity of diabetes in Nigeria might be connected with this great omission. } \\
\text { While the non-consideration of periodontitis appears to be the missing link for unexplained poor glycemic control among Nigerian } \\
\text { diabetics, further studies in the form of surveying Nigerian diabetologists or interviews are needed to fully establish this missing link. }\end{array}$} \\
\hline \multicolumn{4}{|c|}{$\begin{array}{l}\text { Table 1: What we did: The process of using metaethnography and narrative synthesis to arrive propose a hypothesis. Hypothesis "Nigerian diabetologists appear unaware } \\
\text { of the link between periodontitis and poor glycemic control." }\end{array}$} \\
\hline \multicolumn{2}{|l|}{ Database } & Hits & Search Period \\
\hline \multicolumn{2}{|l|}{ Cochrane Library } & 9 & All time \\
\hline \multicolumn{2}{|l|}{ PubMed (Including Medline) } & 709 & All time \\
\hline \multicolumn{2}{|c|}{ Mesh (MEDICAL SUBJECT HEADINGS (MeSH) } & 0 & All time \\
\hline \multicolumn{2}{|l|}{ AJOL } & 32 & All time \\
\hline
\end{tabular}

Table 2a: Search results using the search phrase: Nigeria AND (diabetes OR diabetic OR diabetics). A total of 750 initial hits resulted from a search of the stated databases.

\begin{tabular}{|l|l|}
\hline Inclusion Criteria & Exclusion criteria \\
\hline Nigerian Study & Studies by other experts aside diabetologists \\
\hline Reported in English language & Papers not limited to Nigeria \\
\hline Human subjects & Case reports \\
\hline Glycemic control" / "control" of diabetes & Reviews \\
\hline Study carried out by diabetologists & Observational studies \\
\hline Interventional studies & \\
\hline
\end{tabular}

Table 2b: Inclusion \& Exclusion Criteria. 6 inclusion and 5 inclusion criteria were applied to the initial pool of 750 studies which resulted in the final list of 31 included studies. 
Based on the above, a total of 31 qualifying studies which met our criteria were included in the review. No other rigorous exclusion criteria were included. (Table2b, Figure 1)

\section{Quality assessment}

There's much confusion in literature and lack of consensus on whether quality assessment of publications should form an integral part of a metaethnography or not. We adopted and modified the list of criteria used by [7] to make the criteria relevant to our research question. Our results were expressed in percentages to give readers a clearer picture of the scenario.

Application of the modified quality criteria revealed that most of the Nigerian studies were strong on methodology, evidence-based conclusions and statement of study objectives. However, most studies were weak on adequate description and appropriateness of sampling methods. There was a rough balance among studies on adequate description of statistical tools and adequate description of study settings. However, based on the limitation that most study (26 of 31) assessments were based on abstracts, we followed the example of [7] and decided not to exclude any study on the basis of quality assessment scores alone (Table 3).

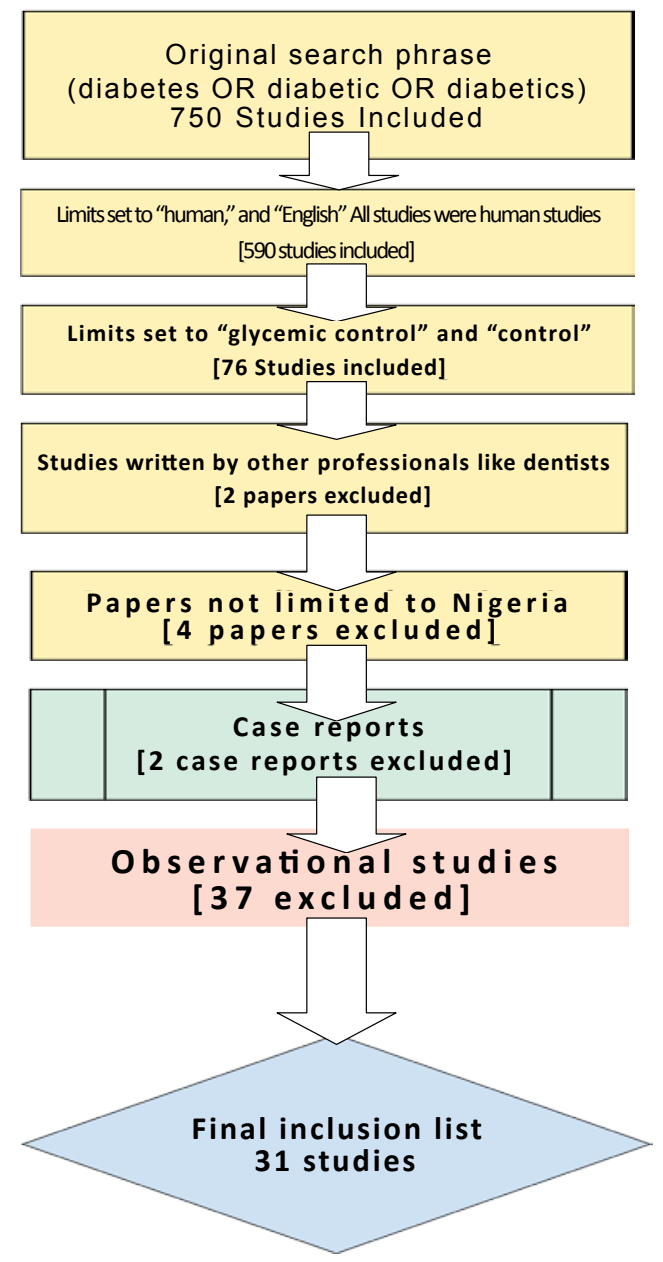

Figure 1: Inclusion and Exclusion Flow Chart. The selection process: 750 initial hits were trimmed down to 31 studies through a set of inclusion and exclusion criteria as stated above.

\begin{tabular}{|l|c|c|}
\hline QA Criterion & $\begin{array}{c}\text { QA Criterion } \\
\text { Met (\%) }\end{array}$ & $\begin{array}{c}\text { QA Criterion Not } \\
\text { Met (\%) }\end{array}$ \\
\hline Study Aim/Objective Stated & $20(64.5)$ & $11(35.5)$ \\
\hline Study Methodology Justified & $25(80.6)$ & $6(19.4)$ \\
\hline Study Context Described & $16(51.8)$ & $15(48.2)$ \\
\hline Sampling Method Appropriate & $13(41.9)$ & $18(58.1)$ \\
\hline Statistical Analysis Appropriate & $12(58.7)$ & $19(61.3)$ \\
\hline Conclusions Supported by Evidence & $21(67.7)$ & $10(32.3)$ \\
\hline Periodontitis Mentioned/Considered & 0 & 0 \\
\hline
\end{tabular}

Table 3: Quality Assessment Criteria and Scores. Results of quality assessment of publications based on 7 criteria. No paper was excluded based on quality assessment results. None of the publications mentioned or considered periodontitis.

\section{Reading the Studies and Determining Order of Constructs}

As interpreted by Atkins and coworkers [7], this step should involve reading studies and determining the order of constructs. However, we found that most of our studies couldn't be categorized into these constructs without undue monotony. This conclusion emanates from the fact that virtually all the conclusions would fit into authors' interpretations of observations or results of interventions. This would make all our constructs 2 nd order constructs which would result in undue monotony. We therefore decided to skip this step in our review.

Determining How the Studies are Related and Translating Studies into One Another

Since these two steps appear close in our interpretation, we decided to combine the two steps resulting in two tables. We decided to introduce colour-matching of the tables in order to make for easy reason and comparison of our initial synthesis with our reciprocal translations. Given the methods used by Atkins and coworkers [7], we arranged our studies into a chronological order for the purpose of comparison to translate one study into another, we decide to make use grouping and tabulation -- tools recommended in developing a narrative synthesis as recommended by After this, we adopted the principle of reciprocal translation as explained by Atkins and coworkers [7] and recommended as a technique for exploring relationships by Jennie Popay and colleagues [8]. We adopted this approach for two main reasons. First, there's much confusion on the actual process of metaethnography and secondly, to avoid the easy trap of losing sacrificing the rich details of previous individual studies on the altar of some "higher interpretation" of the findings of previous studies. (Table $4 \& 5)$

\section{Synthesizing_Translations}

The process for synthesizing translations is quite unclear as observed by [7]. For the purpose of our review, we decided that the narrative translation tool of tabulation combined with a modified form of reciprocal translation expressed in step 5 covered the requirements of the current step (6).

\section{Expressing the Synthesis}

From the foregoing so far, we can confidently express the argument/ hypotheses that

1. Most Nigerian studies on diabetes have centered on microangiopathy, mortality and determinants of glycemic control. 
Citation: Nwhator SO, Adedigba MA (2012) Is Periodontitis the Missing Link? A Metaethnographic Review of Glycemic Control Measures by Nigerian Diabetologists. Dentistry 2:121. doi:10.4172/2161-1122.1000121

Page 4 of 6

\begin{tabular}{|c|c|c|c|c|c|c|}
\hline Author/s [Ref. No] & Main Outcome Measure & $\mathrm{N}$ & $\begin{array}{l}\text { Special Subject } \\
\text { Features }\end{array}$ & Conclusions & $\begin{array}{l}\text { Glycemic } \\
\text { Control } \\
\text { Attempted/ } \\
\text { Advocated }\end{array}$ & Main Recommendation \\
\hline Oli [9] & Remissions & 43 & $\begin{array}{l}\text { Required insulin for } \\
\text { initial control }\end{array}$ & Remissions remain unexplained & Attempted & None \\
\hline Onyeme et al. [10] & $\mathrm{HbA} 1$ usefulness & $?$ & $\begin{array}{l}\text { Various: DM, } \\
\text { Anemia, HBSS }\end{array}$ & $\mathrm{HbAS}$ has reducing effect on the $\% \mathrm{HbA} 1$ & Attempted & $\begin{array}{l}\text { Further investigation } \\
\text { necessary }\end{array}$ \\
\hline Oli and Ikeakor [11] & High carbohydrate effect & 160 & Non-obese NIDDM & No effect on glycemic control & Attempted & $\begin{array}{l}\text { Carbohydrate maybe } \\
\text { beneficial }\end{array}$ \\
\hline Erasmus et al. 12] & Diabetic retinopathy & 377 & $\begin{array}{l}\text { Mature cataract } \\
\text { patients excluded }\end{array}$ & Diabetic retinopathy on the increase & Advocated & $\begin{array}{l}\text { Stress preventive } \\
\text { measures }\end{array}$ \\
\hline Akanji et al. [13] & Microangiopathy & 50 & Diabetic patients & Hypertension and infection critical & Attempted & $\begin{array}{l}\text { Encourage early } \\
\text { presentation }\end{array}$ \\
\hline Akanji et al. [14] & Keiroarthropathy & 256 & $\begin{array}{l}\text { Ambulant diabetic } \\
\text { patients }\end{array}$ & Racial factors affect Keiroarthropathy & Attempted & None \\
\hline Famuyiwa et al. [15] & Glycohaemoglobin levels & 54 & $\begin{array}{l}\text { Healthy pregnant } \\
\text { Nigerian women }\end{array}$ & Cord blood and maternal $\mathrm{GHb}$ related & Advocated & $\begin{array}{l}\text { Optimizing glycemic } \\
\text { control }\end{array}$ \\
\hline Bella [16] & IDDM Demographics & 57 & IDDM & $75 \%$ of subjects were poorly controlled & Advocated & $\begin{array}{l}\text { Diabetic relief measures } \\
\text { needed }\end{array}$ \\
\hline Akanji et al. [17] & Plasma TAG clearance & 32 & $\begin{array}{l}\text { NIDDM and healthy } \\
\text { controls }\end{array}$ & Postprandial lipaemia is multifactorial & Attempted & None \\
\hline Akanji et al. [18] & LCAT activity determinants & 19 & $\begin{array}{l}\text { Obese and non- } \\
\text { obese NIDDM }\end{array}$ & Glycaemia and BMI affect LCAT activity & Attempted & $\begin{array}{l}\text { Drug and dietary } \\
\text { intervention }\end{array}$ \\
\hline Agboola-Abu et al. [19] & Dyslipidaemia & 36 & NIDDM & Glycemic control improves Outcome & Attempted & Improve glycemic control \\
\hline Kolawole and Ajayi [20] & Mortality prognosis indices & 51 & $\begin{array}{l}\text { Hypertensive- } \\
\text { diabetic, NIDDM }\end{array}$ & Prognosis in 1999 diabetics, still dismal & Advocated & $\begin{array}{l}\text { Early, intensive glycemic } \\
\text { control }\end{array}$ \\
\hline Agboola-Abu et al. [21] & Dyslipidaemia & 35 & NIDDM & $\begin{array}{l}\text { Oral hypoglycemics didn't affect } \\
\text { outcome }\end{array}$ & Attempted & None \\
\hline Imam et al. [22] & Autonomic neuropathy & 100 & Diabetic patients & Poor control confused with neuropathy & Advocated & $\begin{array}{l}\text { Perform autonomic } \\
\text { function tests }\end{array}$ \\
\hline Ogunlade et al. [23] & Limb amputation patterns & 101 & Amputees & Glycemic control reduces amputations & Advocated & Improve glycemic control \\
\hline Nwosu [24] & Diabetic retinopathy & N/A & $\begin{array}{l}\text { Nigerian review } \\
\text { article }\end{array}$ & Diabetic retinopathy increasing in Nigeria & Advocated & $\begin{array}{l}\text { Urgent DM care } \\
\text { guidelines needed }\end{array}$ \\
\hline Rotimi et al. [25] & $\begin{array}{l}\text { Retinopathy and cataract } \\
\text { incidence }\end{array}$ & 840 & $\begin{array}{l}\text { Nigerian and Ghana } \\
\text { Diabetics }\end{array}$ & Low outcome prevalence in 1 st 5 Years & Advocated & $\begin{array}{l}\text { Eye exam at first } \\
\text { hyperglycaemia }\end{array}$ \\
\hline Puepet et al. [26] & Biochemical profiles in DM & 75 & Diabetic patients & Abnormalities common in Type 2 DM & Advocated & $\begin{array}{l}\text { Preventive glycemic } \\
\text { control }\end{array}$ \\
\hline Kidmas et al. [27] & Indications, morbidity, mortality & 87 & Amputees & Early presentation and appropriate & Advocated & $\begin{array}{l}\text { Community health } \\
\text { education }\end{array}$ \\
\hline Abioye-Kuteyi et al. [28] & Diet and glycemic control & 33 & Truncal obesity & Dietary advice affects outcome measure & Advocated & $\begin{array}{l}\text { Physicians need dietary } \\
\text { mgt skills }\end{array}$ \\
\hline Ibanga et al. [29] & $\begin{array}{l}\text { Control and corpuscular } \\
\text { fragility }\end{array}$ & 108 & $\begin{array}{l}\text { Diabetics /non- } \\
\text { diabetic controls }\end{array}$ & $\begin{array}{l}\text { Hyperglycaemia affects RBC membrane } \\
\text { fragility }\end{array}$ & Advocated & None \\
\hline Kolawole et al. [30] & Management goal attainment & 133 & $\begin{array}{l}\text { Diabetes health care } \\
\text { providers }\end{array}$ & Very few patients attained targets & Advocated & $\begin{array}{l}\text { Periodic effectiveness } \\
\text { evaluation }\end{array}$ \\
\hline Gadzama et al. [31] & $\begin{array}{l}\text { Biochemistry laboratory } \\
\text { requests }\end{array}$ & 218 & Diabetic patients & Proper utilisation of laboratory tests & Advocated & Team work approach \\
\hline Adetunji et al. [32] & Microalbuminuria & 50 & $\begin{array}{l}\text { Non-proteinuric } \\
\text { diabetics }\end{array}$ & $50 \%$ had suboptimal glycemic control & Advocated & None \\
\hline $\begin{array}{l}\text { Akinosun and Bolajoko } \\
{[33]}\end{array}$ & Total antioxidant status & 40 & $\begin{array}{l}\text { Type } 2 \text { diabetics / } \\
\text { healthy controls }\end{array}$ & $\begin{array}{l}\text { Glycemic control reduces outcome } \\
\text { measure }\end{array}$ & Attempted & $\begin{array}{l}\text { Control reduces free } \\
\text { radicals }\end{array}$ \\
\hline Gadzama et al. [34] & Diagnostic laboratory role & N/A & $\begin{array}{l}\text { Nigerian review } \\
\text { article }\end{array}$ & $\begin{array}{l}\text { Modern laboratories important in } \\
\text { management }\end{array}$ & Advocated & Create required awareness \\
\hline Odusan et al. [35] & Cardiac autonomic neuropathy & 108 & $\begin{array}{l}\text { Type } 2 \text { diabetic } \\
\text { patients }\end{array}$ & $\begin{array}{l}\text { Outcome is common among type } 2 \\
\text { diabetics }\end{array}$ & Attempted & None \\
\hline Yusuff et al. [36] & Patient compliance/adherence & 400 & Diabetic patients & Glycemic control in $33 \%$ of patients & Attempted & None \\
\hline Ajayi and Ajayi [37] & Diabetic admission outcomes & 118 & Diabetic admissions & DM accounted for $4.4 \%$ of all admissions & Advocated & $\begin{array}{l}\text { Establish DM specialist } \\
\text { clinics }\end{array}$ \\
\hline Ikem et al. [38] & Limited joint mobility & 139 & $\begin{array}{l}\text { Type } 2 \text { diabetics / } \\
\text { healthy controls }\end{array}$ & $\begin{array}{l}\text { Subjects have moderately severe } \\
\text { outcome and Poor glycemic control in } \\
85 \%\end{array}$ & Advocated & None \\
\hline Chijioke et al. [4] & DM mortality patterns & 785 & $\begin{array}{l}\text { Case notes of type } 2 \\
\text { diabetics }\end{array}$ & $\begin{array}{l}\text { Type } 2 \mathrm{DM} \text { is a common cause of } \\
\text { morbidity and mortality in Nigeria }\end{array}$ & Advocated & $\begin{array}{l}\text { Early diagnosis and proper } \\
\text { management }\end{array}$ \\
\hline
\end{tabular}

Table 4: An analysis of how the studies are related and translating studies into one another based on

Main Outcome Measure, Sample Size, Special Subject Features, Conclusions, Whether or Glycemic Control Attempted/Advocated, Main Recommendation of Study. 


\begin{tabular}{|c|c|c|c|c|}
\hline Outcome Measure & $\begin{array}{l}\text { Number } \\
\text { of Studies } \\
(\%)\end{array}$ & $\begin{array}{l}\text { Main Argument/Thrust of } \\
\text { Findings } \\
\text { (Modified Reciprocal } \\
\text { Translation) }\end{array}$ & $\begin{array}{l}\text { Main Argument/Thrust of } \\
\text { Recommendations } \\
\text { (Modified Reciprocal Translation) }\end{array}$ & Comments \\
\hline $\begin{array}{l}\text { Demographic and } \\
\text { others }\end{array}$ & $5(16.1)$ & $\begin{array}{l}\text { Remission remains } \\
\text { unexplained in cases. Huge } \\
\text { percentage poorly controlled }\end{array}$ & Varied & $\begin{array}{l}\text { "Unexplained " cases makes case for periodontal } \\
\text { evaluation }\end{array}$ \\
\hline $\begin{array}{l}\text { Microangiopathy } \\
\text { (Retinopathy \& } \\
\text { Neuropathy) }\end{array}$ & $8(25.8)$ & $\begin{array}{l}\text { Microangiopathy is } \\
\text { progressive, common among } \\
\text { Nigerian diabetics and often } \\
\text { a reflection of poor glycemic } \\
\text { control }\end{array}$ & $\begin{array}{l}\text { Early diagnosis, Early Eye examination, } \\
\text { preventive management through proper } \\
\text { glycemic control, performs autonomic } \\
\text { function tests and Urgent need to establish } \\
\text { standardized care guidelines }\end{array}$ & $\begin{array}{l}\text { Standardized care guidelines should include } \\
\text { periodontal examination }\end{array}$ \\
\hline Mortality and Morbidity & $5(16.1)$ & $\begin{array}{l}\text { Morbidity and mortality of DM } \\
\text { still high in Nigeria }\end{array}$ & $\begin{array}{l}\text { Early diagnosis, early intensive glycemic } \\
\text { control and community health education, } \\
\text { DM specialist clinic }\end{array}$ & $\begin{array}{l}\text { "Intensive glycemic control" will fail in patients suffering } \\
\text { from periodntitis. Therefore, adequate periodontal } \\
\text { evaluation and management is necessary. DM } \\
\text { specialist clinics should be multidisciplinary }\end{array}$ \\
\hline Lipidaemia & $4(12.9)$ & $\begin{array}{l}\text { Proprandial lipidaemia is } \\
\text { multifactorial. Improved by } \\
\text { optimal glycemic control }\end{array}$ & Improve glycemic control & $\begin{array}{l}\text { Adequate periodontal evaluation and management will } \\
\text { help improve glycemic control }\end{array}$ \\
\hline $\begin{array}{l}\text { Glycemic control } \\
\text { determinants and } \\
\text { effects }\end{array}$ & $5(16.1)$ & $\begin{array}{l}\text { Role of diet, controversial. } \\
\text { Optimal glycemic control } \\
\text { achieved only in a small } \\
\text { proportion of patients }\end{array}$ & $\begin{array}{l}\text { Need for improvement and effectiveness } \\
\text { of glycemic control measures. Oral } \\
\text { hypoglycemics largely failed. Need for } \\
\text { dietary management skills and continuous } \\
\text { evaluation of effectiveness }\end{array}$ & $\begin{array}{l}\text { Urgent need to increase the awareness of Nigerian } \\
\text { diabetologists about how periodontitis affects glycemic } \\
\text { control through a "train the trainers" scheme }\end{array}$ \\
\hline $\begin{array}{l}\text { Biochemical profiles and } \\
\text { indicators }\end{array}$ & 4 (12.9) & $\begin{array}{l}\text { Biochemical tests under- } \\
\text { utilized and at times } \\
\text { unavailable }\end{array}$ & Need for modern laboratory facilities & $\begin{array}{l}\text { Advanced rapid tests for periodntitis should be } \\
\text { incorporated }\end{array}$ \\
\hline
\end{tabular}

Table 5: Groupings and Reciprocal Translation based on

Outcome Measure, Number of Studies, Main Argument/Thrust of Findings, (Modified Reciprocal Translation), Main Argument/Thrust of Recommendations (Modified Reciprocal Translation), Plus Our Comments/Recommendations

Definition of abbreviations:

N = Sample Size HBAS = Sickle; cell trait (Heterozygous); DM = Diabetes Mellitus; Hb = Hemoglobin; HBSS = Sickle Cell Disease (Homozygous); HbA1 = Glycosylated Hemoglobin NIDDM = Non-Insulin Dependent Diabetes Mellitus; GHb = Glycohaemoglobin; IDDM = Insulin Dependent; Diabetes Mellitus TAG= Triacylglycerols LCAT= lecithin: Cholesterol AcylTransferase

2. None of the studies by Nigerian diabetologists have mentioned, considered or advocated periodontal evaluation as part of glycemic control protocol for Nigerian diabetics.

3. Nigerian diabetologists appear unaware of the link between periodontitis and poor glycemic control.

4. Current unacceptable mortality and morbidity of diabetes in Nigeria might be connected with this great omission.

5. Periodontitis is the missing link for unexplained poor glycemic control among Nigerian diabetics.

As in other parts of the world, there are no such experts that we are aware of who are specifically in charge of diabetes and periodontal disease as a combined discipline. Nigeria is however endowed with many expert diabetologists who treat diabetes on one hand and extremely few periodontologists who treat periodontal disease. The focus of our paper is to encourage collaboration between these two groups of experts for the ultimate benefit of the Nigerian diabetic patient.

\section{Conclusion}

The message of this metaethnography combined with a bit of narrative synthesis is clear: The morbidity and mortality of type 2 diabetes mellitus in Nigeria remains unacceptably high. The 1978 observations of Oli [9] expressing concerns about "unexplained remissions," and more recent literature pointing to the associations between periodontitis and poor glycemic control - [1,2]. Han et al. [39] have shown that periodontitis predisposes to metabolic syndrome and diabetes while Lakschevitz et al. [40] presented evidence of the establishment of the adverse effect of periodontitis.
In a recent study, Colombo and coworkers demonstrated that Periodontal Disease Decreases Insulin Sensitivity and Insulin Signaling [41]. These are just the most recent among hundreds of studies. The evidence is overwhelming.

We have attempted to paint the obvious picture -- the average Nigerian diabetologist appears UNAWARE of the effects of periodontitis on metabolic control in diabetes mellitus.

One case report is of special interest and was included in the discussion section because the authors had dismissed the association between diabetes and periodontitis based on a single case report and what they termed "personal observations." [42]

So, is periodontitis the missing link in glycemic control attempts by Nigerian diabetologists? Only further studies in the form of surveys/ interviews of Nigerian diabetologists can answer this question in the affirmative.

\section{Recommendations}

We recommend the following;

1. Further studies in the form of surveys and /or interviews of Nigerian diabetologists to establish current knowledge and practice of this group of experts as it relates to ruling out periodontitis in glycemic control.

2. We recommendation (1) above confirm my fears, we recommend urgent steps to increase the awareness of the Nigerian diabetologists about the adverse effects of periodontitis on metabolic control.

3. The medical curriculum should include more modules in 
dentistry and urgent, sustained collaborative conferences and continuing education courses should be organized between Nigerian diabetologists and periodontologists.

\section{References}

1. Lalla E, Papapanou PN (2011) Diabetes mellitus and periodontitis: a tale of two common interrelated diseases. Nat Rev Endocrinol 7: 738-748.

2. Deschner J, Haak T, Jepsen S, Kocher T, Mehnert H, et al. (2011) [Diabetes mellitus and periodontitis. Bidirectional relationship and clinical implications. A consensus document]. Internist (Berl) 52: 466-477.

3. Enweluzo GO, Giwa SO, Adekoya-Cole TO, Mofikoya BO (2010) Profile of amputations in Lagos University Teaching Hospital, Lagos, Nigeria. Nig Q J Hosp Med 20: 205-208

4. Chijioke A, Adamu AN, Makusidi AM (2010) Mortality patterns among type 2 diabetes mellitus patients in Ilorin, Nigeria. JEMDSA 15: 79-82.

5. Ekrikpo UE, Udo Al, Ikpeme EE, Effa EE (2011) Haemodialysis in an emerging centre in a developing country: a two year review and predictors of mortality. BMC Nephrol 12: 50

6. Odubanjo MO, Okolo CA, Oluwasola AO, Arije A (2011) End-stage renal disease in Nigeria: an overview of the epidemiology and the pathogenetic mechanisms. Saudi J Kidney Dis Transpl 22: 1064-1071.

7. Atkins S, Lewin S, Smith H, Engel M, Fretheim A, et al. (2008) Conducting a meta-ethnography of qualitative literature: lessons learnt. BMC Med Res Methodol 8: 21.

8. http://www.lancs.ac.uk/shm/research/nssr/index.htm

9. Oli JM (1978) Remittant diabetes mellitus in Nigeria. Trop Geogr Med 30: 57 62.

10. Onyemelukwe GC, Isah HS, Mba EC, Awunnor-Renner C, Mohammed I (1983) Glycosylated haemoglobin (HbA1) for diabetic control in Africans; preliminary findings with the microcolumn technique. Trop Geogr Med 35: 347-351.

11. Oli JM, Ikeakor IP (1984) High carbohydrate diet in the management of nonobese non-insulin-dependent Nigerian diabetics. Hum Nutr Appl Nutr 38: 479486 .

12. Erasmus RT, Alanamu RA, Bojuwoye B, Oluboyo P, Arije A (1989) Diabetic retinopathy in Nigerians: relation to duration of diabetes, type of treatment and degree of control. East Afr Med J 66: 248-254.

13. Akanji AO, Famuyiwa OO, Adetuyibi A (1989) Factors influencing the outcome of treatment of foot lesions in Nigerian patients with diabetes mellitus. Q J Med 73: $1005-1014$

14. Akanji AO, Bella AF, Osotimehin BO (1990) Cheiroarthropathy and long term diabetic complications in Nigerians. Ann Rheum Dis 49: 28-30.

15. Famuyiwa OO, Amadin RA, Adelusi BO (1990) Glycosylated haemoglobin levels in healthy pregnant Nigerian women and in the cord blood of their newborn babies. Afr J Med Med Sci 19: 83-88.

16. Bella AF (1992) A prospective study of insulin-dependent diabetic Nigerian Africans. J Natl Med Assoc 84: 126-128.

17. Akanji AO, Nzegwu AA, Agbedana EO (1992) Some determinants of postprandial lipaemia in Nigerian diabetic and non-diabetic subjects. $\mathrm{Br} \mathrm{J}$ Nutr 68: 153-162.

18. Akanji AO, Agbedana EO (1995) Glycaemia and body mass as determinants of plasma lecithin: cholesterol acyltransferase activity in Nigerian patients with non-insulin dependent diabetes mellitus. Clin Chim Acta 238: 35-42.

19. Agboola-Abu CF, Ohwovoriole AE, Akinlade KS (2000) The effect of glycemic control on the prevalence and pattern of dyslipidaemia in Nigerian patients with newly diagnosed non insulin dependent diabetes mellitus. West Afr J Med 19: 27-33.

20. Kolawole BA, Ajayi AA (2000) Prognostic indices for intra-hospital mortality in Nigerian diabetic NIDDM patients. Role of gender and hypertension. J Diabetes Complications 14: 84-89.
21. Agboola-Abu CF, Ohwovoriole AE, Akinlade KS (2000) The effect of ora hypoglycemic agents on dyslipidaemia in Nigerian patients with newly diagnosed non-insulin dependent diabetes mellitus--a prospective study. West Afr J Med 19: 126-131.

22. Imam I, Oluwole OS, Abbiyesuku F (2002) The significance of autonomic symptoms in Nigerian diabetics. Afr J Med Med Sci 31: 235-237.

23. Ogunlade SO, Alonge TO, Omololu AB, Gana JY, Salawu SA (2002) Major limb amputation in Ibadan. Afr J Med Med Sci 31: 333-336.

24. Nwosu SN (2003) Diabetic retinopathy: management update. Niger Postgrad Med J 10: 115-120

25. Rotimi C, Daniel H, Zhou J, Obisesan A, Chen G, et al. (2003) Prevalence and determinants of diabetic retinopathy and cataracts in West African type 2 diabetes patients. Ethn Dis 13: S110-117.

26. Puepet FH, Agaba El, Chuhwak EK (2003) Some metabolic abnormalities in type 2 diabetic patients in Jos, north central Nigeria. Niger J Med 12: 193-197.

27. Kidmas AT, Nwadiaro CH, Igun GO (2004) Lower limb amputation in Jos, Nigeria. East Afr Med J 81: 427-429.

28. Abioye-Kuteyi EA, Ojofeitimi EO, ljadunola KT, Fasanu AO (2005) Assessment of dietary knowledge, practices and control in type 2 diabetes in a Nigerian teaching hospital. Niger J Med 14: 58-64.

29. Ibanga IA, Usoro CA, Nsonwu AC (2005) Glycaemic control in type 2 diabetics and the mean corpuscular fragility. Niger J Med 14: 304-306.

30. Kolawole BA, Adegbenro C, Ayoola ZO, Opebiyi B (2005) Diabetes mellitus related treatment goals: awareness and attainment in the Ife-ljesa zone of south-western Nigeria. Afr J Med Med Sci 34: 389-394.

31. Gadzama AA, Mshelia DS, Nyandaiti Y (2006) Pattern of biochemistry laboratory requests and results in north eastern Nigeria. Niger Postgrad Med J 13: 99-102.

32. Adetunji OR, Adeleye JO, Agada NO, Salako BL (2006) Microalbuminuria and clinical correlates in black African patients with type 2 diabetes. West Afr J Med 25: $279-283$

33. Akinosun OM, Bolajoko EB (2007) Total antioxidant status in type 2 diabetic patients: experience at University College Hospital (UCH) Ibadan, Nigeria Niger J Clin Pract 10: 126-129.

34. Gadzama AA, Nyandaiti Y, Mshelia DS (2008) Role of a diagnostic laboratory in the management of diabetes mellitus. Niger J Clin Pract 11: 67-71.

35. Odusan O, Familoni OB, Raimi TH (2008) Correlates of cardiac autonomic neuropathy in Nigerian patients with type 2 diabetes mellitus. Afr $\mathrm{J}$ Med Med Sci 37: 315-320.

36. Yusuff KB, Obe O, Joseph BY (2008) Adherence to anti-diabetic drug therapy and self management practices among type-2 diabetics in Nigeria. Pharm World Sci 30: 876-883.

37. Ajayi EA, Ajayi AO (2009) Pattern and outcome of diabetic admissions at a federal medical center: a 5-year review. Ann Afr Med 8: 271-275.

38. Ikem IC, Ikem RT, Olaogun MO, Owoyemi A, Ola BA (2009) Assessment of limited joint mobility of the hand in Black Africans with diabetes mellitus and in non-diabetics. West Indian Med J 58: 506-511.

39. Han DH, Lim S, Paek D, Kim HD (2011) Periodontitis could be related factors on metabolic syndrome among Koreans: a case-control study. J Clin Periodonto 39: $30-37$

40. Lakschevitz F, Aboodi G, Tenenbaum H, Glogauer M (2011) Diabetes and periodontal diseases: interplay and links. Curr Diabetes Rev 7: 433-439.

41. Colombo NH, Shirakashi DJ, Chiba FY, Sara de Lima Coutinho M, Ervolino E, et al. (2011) Periodontal Disease Decreases Insulin Sensitivity and Insulin Signaling. J Periodontol.

42. Akintewe TA, Kulasekara B, Adetuyibi A (1984) Periodontitis diabetica. A case report from Nigeria. Trop Geogr Med 36: 85-86. 